\title{
A Major Change in the Stratigraphy of the Santorini Volcano in Greece
}

\section{Walter L. Friedrich1, Annette Højen Sørensen 1* , J. Richard Wilson1, Michael Fytikas², Spyridon Pavlides ${ }^{2}$, Samson Katsipis ${ }^{3}$}

\author{
${ }^{1}$ Department of Geoscience, University of Aarhus, Aarhus, Denmark \\ ${ }^{2}$ Department of Geology, Aristotle University of Thessaloniki, Thessaloniki, Greece \\ ${ }^{3}$ Museum of Minerals and Fossils Perissa, Santorini, Greece \\ Email:walter@geo.au.dk, ^annettehs@geo.au.dk,jrw@geo.au.dk,fytikas@geo.auth.gr, pavlides@geo.auth.gr, \\ samkatsipis@gmail.com
}

How to cite this paper: Friedrich, W.L. Sørensen, A.H., Wilson, J.R., Fytikas, M., Pavlides, S. and Katsipis, S. (2017) A Major Change in the Stratigraphy of the Santorini Volcano in Greece. International Journal of Geosciences, 8, 767-780.

https://doi.org/10.4236/ijg.2017.86043

Received: May 18, 2017

Accepted: June 13, 2017

Published: June 16, 2017

Copyright (c) 2017 by authors and Scientific Research Publishing Inc. This work is licensed under the Creative Commons Attribution International License (CC BY 4.0).

http://creativecommons.org/licenses/by/4.0/

c) (i) Open Access

\begin{abstract}
Two prominent and similar pumice series were described on Thera in 1879the Upper and Lower Pumice Series (UPS and LPS). Since then, geologists have treated the two series separately because they seemingly occurred at distinct levels and had different ages. Here we show that these two pumice series are identical; there is no LPS on Santorini. All stratigraphic conclusions based on the LPS from Santorini should therefore be discarded. The water-filled Santorini caldera with its steep inner slopes existed before the eruption. Volcano-tectonic effects in connection with caldera formation created concentric terraces that were mantled by the products of the Late Bronze Age (LBA) eruption. Subsequent erosion only left remnants of the mantle behind. Topographic effects followed by slumping during sedimentation caused confusion of the stratigraphy on the caldera wall. Our results are supported by geological, paleontological and archaeological evidence. Furthermore, the caldera with its minerals, pigments, harbours and hot springs was accessible for the Thereans. This reinterpretation opens new perspectives for archaeological research. The catastrophic LBA eruption (previously called the Minoan eruption) destroyed a flourishing culture on Santorini and impacted neighbouring cultures around $1613 \mathrm{BC}$.
\end{abstract}

\section{Keywords}

Minoan Eruption, Late Bronze Age Eruption, Santorini Volcano

\section{Introduction}

Several scholars visited Santorini (Figure 1(a)) in Greece in the 1870s to study the eruptions on Nea Kameni. Among them was the French geologist Ferdinand 


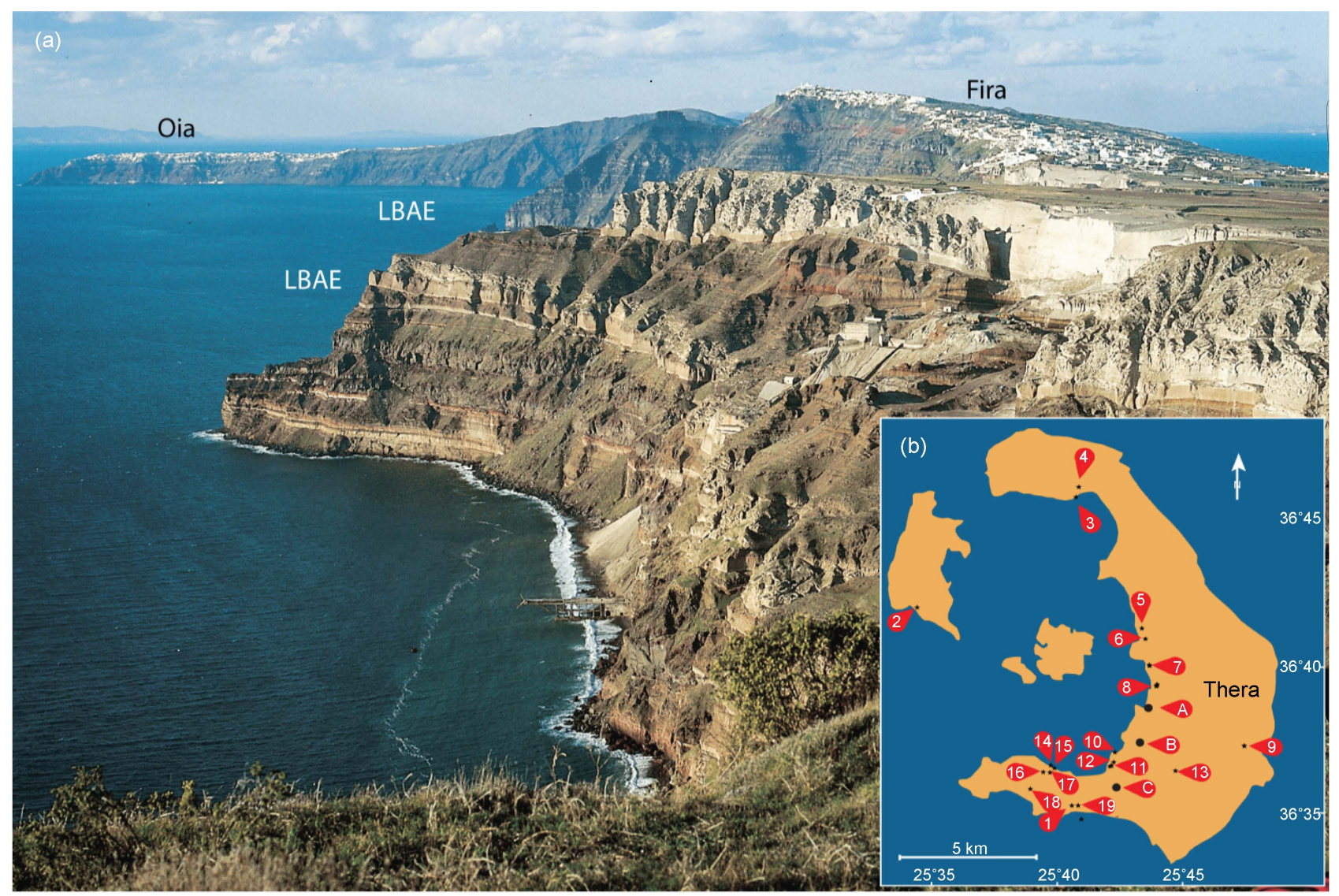

Figure 1. (a) View of Thera facing north. The two prominent pumice series were produced by the Late Bronze Age (LBA) eruption. LBAE = Late Bronze Age eruption products. They rest on concentric terraces that were formed by erosion following a caldera collapse prior to this eruption. (b) (bottom right). Location map of Santorini. The numbers refer to archaeological and geological sites. A, B, C: IGME drill sites. Photo W.L. Friedrich.

Fouqué [1]. He showed that there are two prominent pumice layers on Santorini which he named ponce inferieure and ponce superieure-the Lower Pumice Series (LPS) and the Upper Pumice Series (UPS). He shows the LPS as a continuous layer that underlies other (apparently younger) volcanic rocks on Santorini. The LPS and UPS are similar in their general appearance, but seemingly had different ages. Figure 1(a) summarises the theme of our paper: Are the two pumice layers identical or not?

\section{Upper Pumice Series (UPS) of the LBA Eruption}

The LBA eruption started with precursory activity, followed by air-fall, base surge and pyroclastic flows. The phases, deposits, and effects of the LBA eruption are described in detail elsewhere [2] [3] [4]. A direct and precise date is now available based on radiocarbon analyses of two olive trees that were buried alive in the pumice of this eruption ( $1613 \pm 13$ cal. y BC based on the first olive tree) [5] [6] [7]. This date is about 100 years younger than the conventional archaeological date [6]. The strength of the eruption is a topic of discussion; it is considered to have been the most violent known eruption in the past 10,000 years [8]. 
The tephra of the first phase of the LBA eruption covers the tops of Thera, Therasia and Aspronisi of the Santorini volcanic island group. The wind mostly carried it in a south-easterly direction where it today provides an important marker horizon for geologists and archaeologists. The tephra has been found both in deep-sea cores and on land in Anatolia, the eastern part of Crete, and partly also in the Levant and in Northern Egypt [9] [10] [11] [12] [13].

\section{The Lower Pumice Series (LPS) of the LBA Eruption}

According to Fouqué and later scholars this pumice series (Figure 2) only appears on the lowermost parts of the caldera wall on Thera, more specifically in the lower part of the caldera wall at Oia and between Fira and Cape Akrotiri. In the following, we argue that the LPS and UPS are essentially the same layer. However, a recent study claims to have found the LPS on the island of Anaphi, which lies about $30 \mathrm{~km}$ east of Santorini [14].

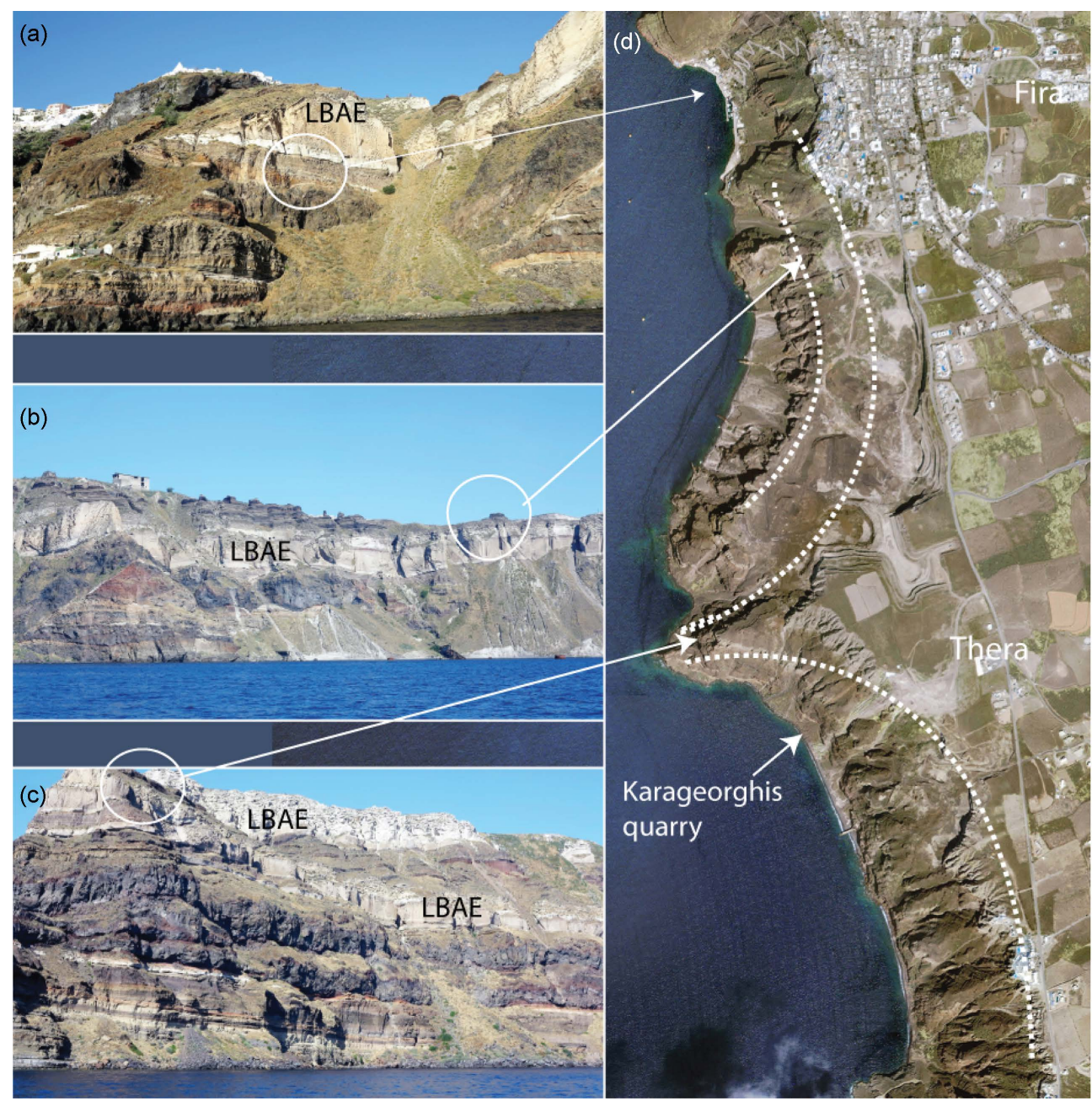

Figure 2. Satellite image, ESA ((d), right) of Thera, the main island of the Santorini volcanic group. (a) Fira Quarry; (b) North of Cape Alonaki; (c) North of Karageorghis quarry where the UPS has been radiocarbon dated by an olive tree found in situ. The lower part of the LBA eruption lies on a downfaulted terrace and contains Cycladic ceramics; (d) Two funnel-shaped collapse structures meet at Cape Alonaki where they produced concentric terraces on the caldera wall. 


\section{History of Research}

Fouqué (1879:206) depicted both pumice layers in a diagram showing Cape Alonaki on the caldera wall of Thera. Furthermore, he extrapolated from the angle of outer slopes of the volcanic edifice that the central part of the Santorini ring island had a height of about 450 meters. He considered that the caldera was created when the volcanic island exploded around 2000 BC. This concept was adopted by generations of geologists for the next 120 years and the two pumice layers were considered to be the products of separate eruptions at the beginning and end of a magmatic cycle, as will be shown below.

In 1936 Neumann van Padang [15] presented a detailed description of the geology of Santorini, including the above-mentioned pumice layers from the caldera wall of Thera. He followed Fouque and concluded that the UPS and LPS were similar, but different, layers that occurred at distinct levels on the caldera wall. He considered that they were deposited by two strong eruptions, each of which produced thick pumice layers and triggered events of caldera formation.

When deep-sea cores of the Eastern Mediterranean became available, Ninkovich and Heezen [16] identified the LPS and UPS from Santorini. Based on the enormous distribution area of the LPS in the Eastern Mediterranean, it was concluded that this eruption must have been bigger than that which produced the UPS. However, in 1985 A. Vinci [17] showed that the so-called LPS ash in deep-sea cores from the Eastern Mediterranean was not derived from Santorini but had a Campanian source.

Pichler and Kussmaul [18] mapped Santorini in 1969-1970 and, concerning the LPS, mainly followed the work of Neumann van Padang. Furthermore, they divided the LPS into LPS1 and LPS2 that they considered came from two different vents emptying the same magma chamber. Ice core signals in the Greenland ice sheet were detected in 1987 and resulted in an age of $1645 \pm 7$ years for the LBA eruption [19]. Sparks and Wilson [20] presented a review of the LBA eruption deposits in 1990.

A study by Vitaliano et al. [21] showed that the chemical compositions of the UPS and LPS could not be distinguished in various geochemical diagrams. However, Druitt et al.'s comparison of LPS1 and LPS2 showed that their chemical compositions lie in the range of the LBA eruption, but at either end of that range [22]. Radiometric ages for LPS1 and LPS2 were presented (K-Ar dating): $203 \pm 24 \mathrm{ka}$ for LPS1 and $180 \mathrm{ka}$ for LPS2. The age of LPS1 is based on obsidian in a welded ignimbrite below Oia.

\section{Was There a Central Cone or a Water-Filled Caldera Prior to the LBA Eruption?}

Heiken and McCoy [23] offered a graphic portrayal of the island before the LBA eruption. Based on fission track analyses of the LPS, Seward et al. [24] calculated an age of 100,000 years. Since 1985 the discussion has focused on the strength of the LBA eruption since underwater investigations around Santorini had revealed more pyroclastic deposits on the sea floor than expected. The strength of the 
LBA eruption therefore increased in the literature [25].

A study of about 1450 calcareous blocks of stromatolites from the Santorini volcano was performed by Eriksen [26]. The stromatolitic blocks had been ejected in the third phase of the LBA eruption. Radiocarbon dating showed that it was possible that they had formed their build-ups in shallow seawater near the later eruption crater inside the water-filled caldera 12,000 years before the LBA eruption. This analysis of the stromatolites proved that the Santorini caldera existed prior to this eruption.

Druitt and Francaviglia [27] demonstrated that pumice on the caldera wall of the LBA eruption dips down towards the caldera, confirming the existence of an earlier caldera.

In 1999 Druitt et al. [22] adopted the ideas of Neumann van Padang that the two pumice series triggered two calderas. They argued for a magmatic megacycle with a time interval of 200,000 years when identical eruption series were created.

\section{Geo-Archaeological Investigations}

Since the 1970s, three of us have been working on Santorini, amongst other places in the now abandoned pumice quarries on Thera and Therasia. Even though the number of good field sites is rapidly decreasing on Santorini due to human activities, it is still possible to get important geological information from the steep walls of the caldera. Modern tools like GIS and GPS are also very useful [27]. From decades of fieldwork and research on the geology of Santorini, we have found that it is necessary to make some general changes in geological interpretations, as we show below.

\section{Concentric Terraces on Thera}

Concentric terraces are closely related to the formation of a caldera. The latter is a volcano-tectonic collapse structure that is commonly sub-circular and funnel shaped. After a strong eruption, when the magma chamber is emptied and the roof of the chamber cannot stand the weight of the overlying material, it sometimes collapses. After the main collapse the caldera wall is unstable for a long time and erosion and down-sliding effect material on the wall. For example, a lava is more durable than tuff and terraces form on the upper surfaces of the more resistant layers.

For Santorini, it could have been the Cape Riva Eruption (around 21,000 years ago) that formed a caldera with concentric terraces on its wall, like those at Cape Alonaki on Thera (Figure 2). Concentric terraces were also recently discovered on the caldera wall above Balos harbour. This observation, together with the rediscovery of a Cycladic house [28] that had been buried under the pumice of the LBA eruption, clearly indicates that there is no Lower Pumice Series material here.

\section{A Cycladic House at Balos Harbour on Thera}

Volcano-tectonic forces on the Akrotiri Peninsula had lifted the marine sediments to a height of $200 \mathrm{~m}$. The uplifted part of it contains marine fossils of 
Plio-Pleistocene age [29]. The peninsula has an in-situ cover of the UPS, whereas the steep slopes are covered by material of the LBA eruption that is resting on narrow terraces which can be followed for several kilometres along the caldera wall of Thera. The volcanic deposits have been partly reworked on the inner side of the caldera. During the surge phase of the eruption pumice was plastered against the steep slope of the caldera wall and subsequently slid down and came to rest on the natural terraces of the old caldera wall.

Due to mining activity (ca. 1850-1900 AD) above Balos harbour where the Cycladic house was found, most of the pumice mantle has been removed, including the ruins of the house. However, the characteristic platform on top of the thick lava is still visible.

Neumann van Padang tried to find the excavation site in 1936 but did not succeed. In a profile he shows "Bu" at a height of $67 \mathrm{~m}$; "Bu" means LPS. Geological maps by later scholars also show LPS in this area.

However, in 2009 we rediscovered the platform where a house with three rooms stood prior to the LBA eruption [30]. We used satellite images together with information provided by the French scientists to find the location. A platform at $62 \mathrm{~m}$ above sea level fitted perfectly with the description. Even the original thickness $(22 \mathrm{~m})$ of pumice that buried the house with the three rooms is visible on the caldera wall below Mount Loumaravi.

\section{Observations around Fira}

The up to $60 \mathrm{~m}$ thick pumice layers below Fira (Figure 3) have the same overall appearance, the same sequence and the same erosional pattern as the UPS in the

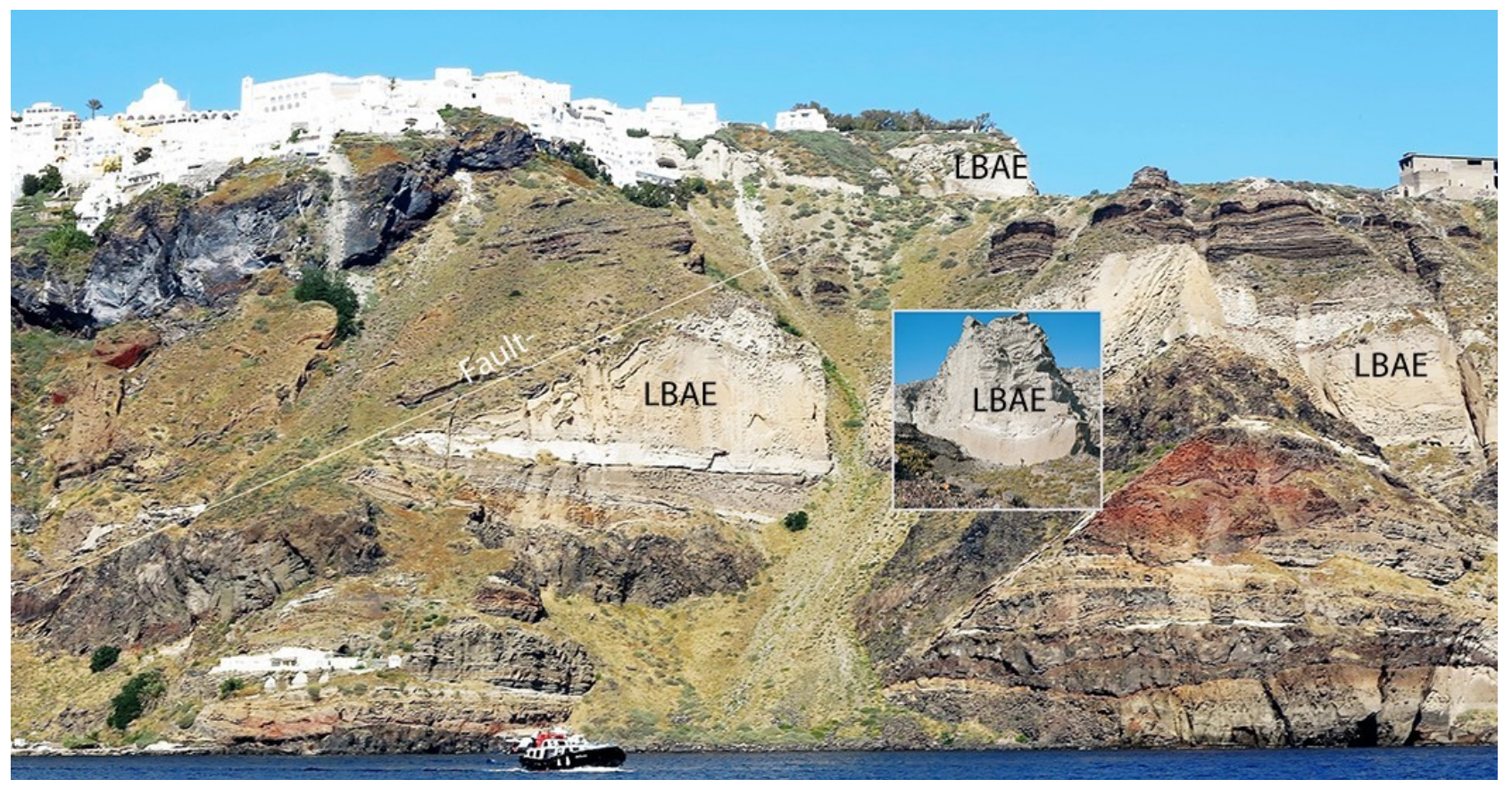

Figure 3. A visual comparison of the so-called "LPS" from the caldera wall below Fira with the LBA eruption products from the nearby Cape Alonaki (inserted photo) shows a striking similarity in the total thickness in the three exposures. Photos W. L. Friedrich. 
nearby Fira quarry. In this quarry there are faults which show that tectonic movements played a role in their development and current position on the caldera wall. In the abandoned pumice quarries near Fira there is an abrupt shift from the lower to the upper products of the LBA eruption. The lowermost part of the UPS is in direct contact with the upper part of the so-called LPS (Figure 4 and Figure 5).

\section{The Karageorghis Quarry on Thera}

In May 1978, WLF [31] found a black patch of charcoal powder in the Karageorghis quarry that had been lying directly under the pumice of the LBA eruption. At first it seemed that this was a heap of branches that a bulldozer had recently crushed, as indicated by the course of bulldozer tracks. A sample of this material was radiocarbon dated, providing a calibrated age of 1700 BC corresponding to other radiocarbon dates of the LBA eruption from Santorini in the 1970s. However, in 2008 the driver of that bulldozer informed WLF that the black powder came from an in situ standing tree which had been destroyed during the mining process. Furthermore, we found ceramic items of Cycladic origin-a closed painted vessel and a larger open unpainted vessel-inside the Karageorghis quarry at a level below that of the destroyed tree. Here the UPS rested on a down-faulted terrace (Figure 6). The late archaeologist Charalambos Sigalas excavated this site. He informed us that human bones and skulls had been found

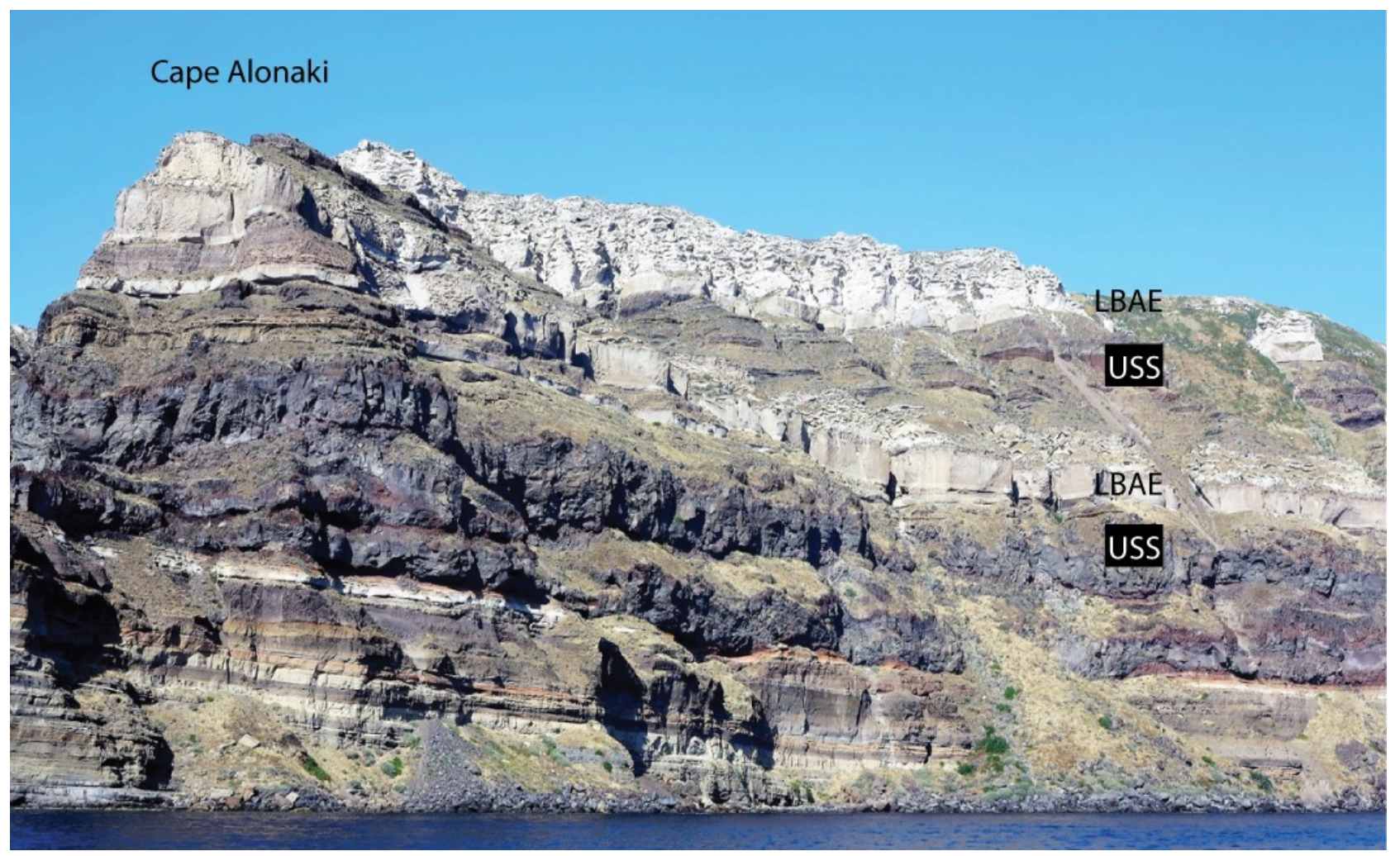

Figure 4. The caldera wall south of Fira provides more information. The LPS here locally has a darker colour; this has been known since the work by Fouqué. This miscolouring is characteristic for those places where the LPS is overlain by black lapilli of the upper scoria series (USS) where rainwater can spill over the underlying pumice. 


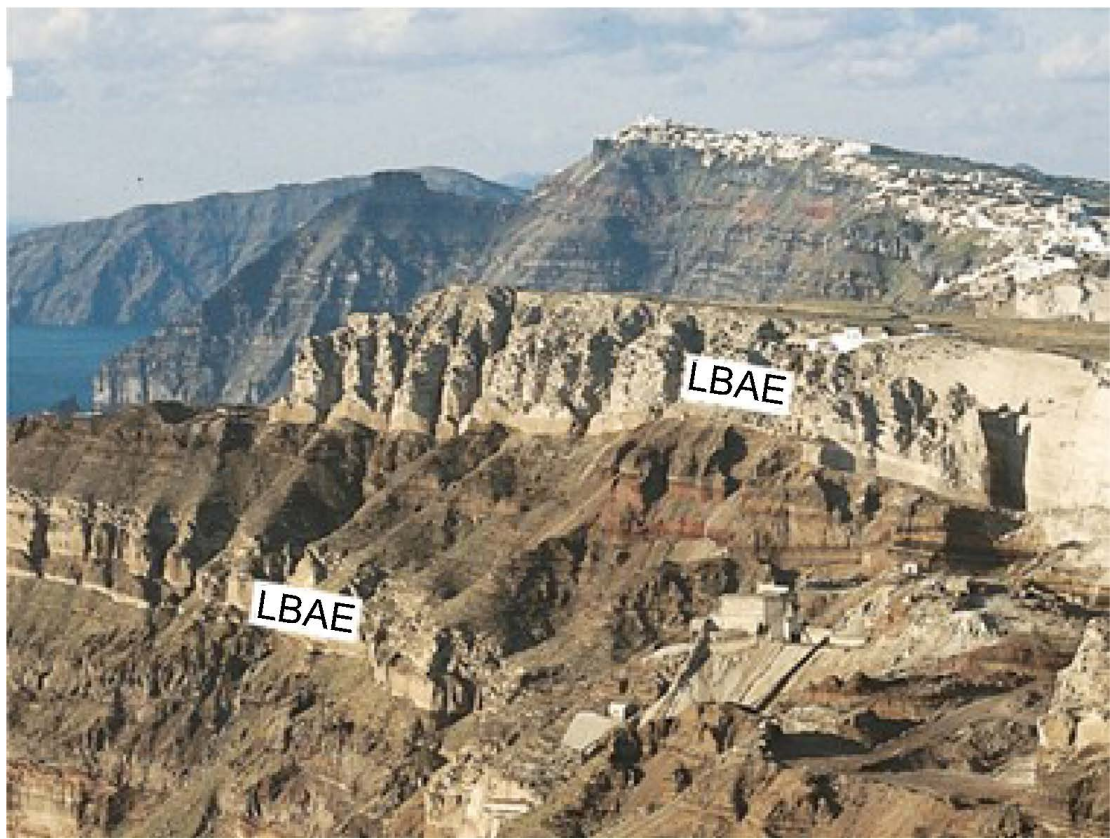

Figure 5. Two levels of exposure of the eruption products merge on top of Cape Alonaki. The lower one is slightly darker due to the overlying black lapilli of the Upper Scoria Series (USS). The LPS and UPS get closer to each other and finally merge in the Karageorghis quarry.

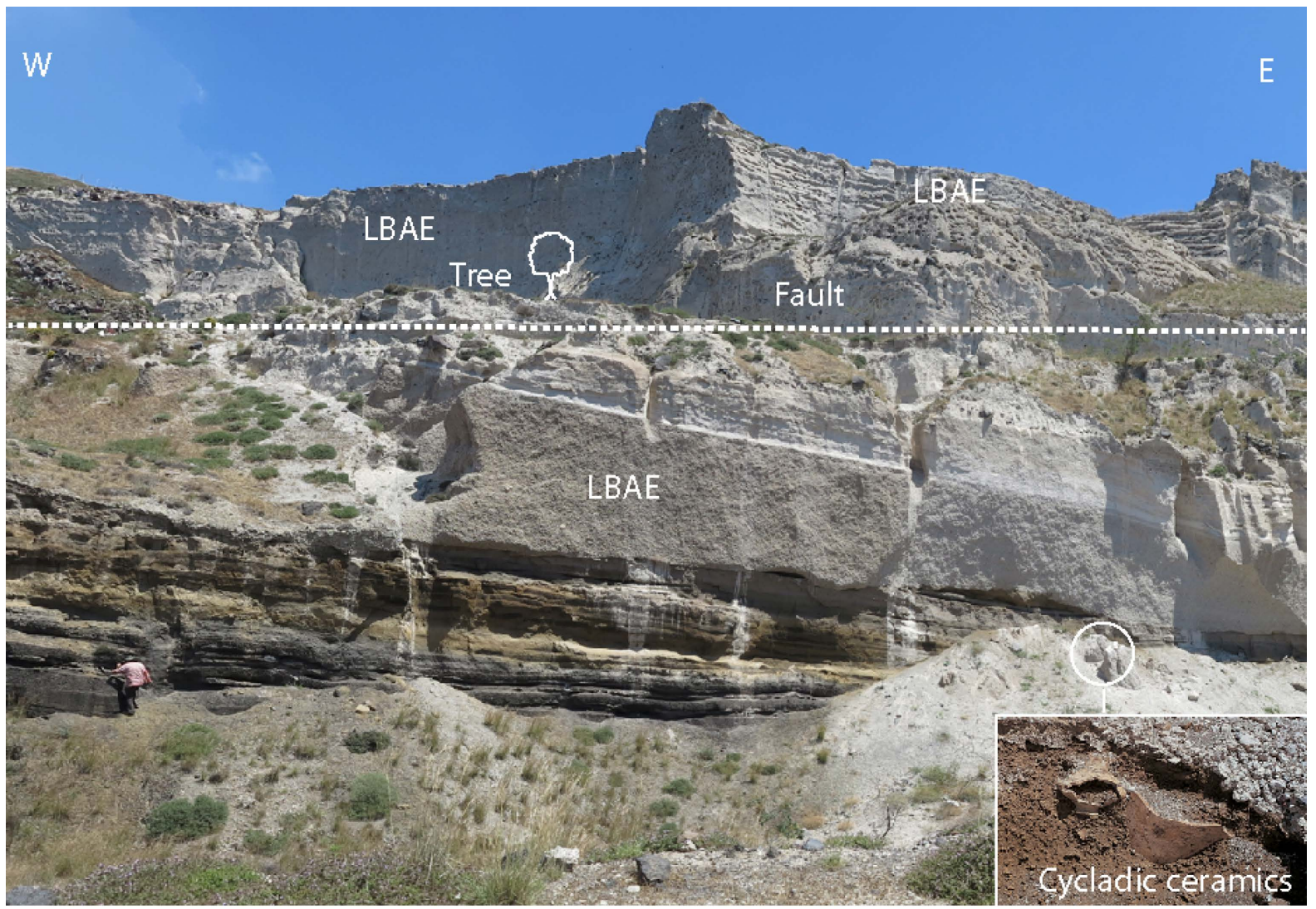

Figure 6. The Karageorghis quarry on Thera. The UPS has been radiocarbon dated by a tree found in situ. The lower part of the UPS lies on a down-faulted (dotted line) terrace and overlies Cycladic ceramics (circle and inserted photo). Both pumice series belong to the LBA eruption. 
there. This area was therefore possibly used as a cemetery in the Bronze Age. The radiocarbon dated tree and the pottery show that the two sections of the profile in this quarry have the same age as the LBA eruption.

The quarry shows, on a small scale, how we could interpret the settings on the nearby caldera wall. In the quarry the radiocarbon date of the tree in the upper part of Figure 6 and the Cycladic age of the lower part show that the pumice of the LBA eruption was deposited on stepwise arranged terraces. Both parts have the same age and belong to the LBA eruption.

The thick pumice layer at Ammoudi, below Oia, which existed before mining started in the second half of the 19th century, belongs to the LBA eruption and not to the LPS, as testified by pottery shards and obsidian tools found below the pumice.

During fieldwork around Oia in 1987, Ulrike Eriksen observed painted pottery [32] under the UPS of the LBA eruption on the caldera wall below Megalo Vouno. It was at the same height on the caldera wall as where Heiken and McCoy [23] had seen deeply weathered rock, indicating that there was an old caldera wall here. The above-mentioned pottery shows that the UPS here was deposited on the inner side of the caldera wall.

\section{Diggings, Drillings and Archaeological Considerations}

In order to obtain data about the horizontal distribution of the so-called LPS we searched for all kinds of information. We know that the LPS was not observed [33] at three drill sites of the Greek Institute of Geology and Mineral Exploration on Thera (Athinios, Aghia Anna and Megalochori (Figure 1(b); letters A-C)).

The people who lived on Thera and Therasia 3600 years ago might have had access to a pumice deposit. Pumice was-and still is-a valuable tool for polishing and grinding purposes. Moreover, it is an excellent material in which to excavate caves (Figure 7). We therefore tried to investigate geological and archaeological sites where the Bronze Age surface is accessible and contacted the scholars who excavated these sites (Figure 1(b); 1 - 19), but no traces of LPS were found.

The discovery of two olive trees buried alive by the pumice of the LBA eruption gave us not only the possibility of dating the eruption directly and precisely, but also the idea of studying the soil-the cultivated field in which the trees grew. A several meters thick weathered tuff is exposed at this site (Figure 1(b); 8). The highest part consists of a ca. $30 \mathrm{~cm}$ thick layer with clear traces of human activity-ploughing, small fragments of ceramics and obsidian, and decayed plant material in the form of moulds of roots and twigs. Here we searched especially for lumps of pumice, but none were found in the several hundred meters long outcrop.

\section{Akrotiri Excavation}

According to C. Doumas (director of the Akrotiri excavation) "isolated artefacts made of pumice" (pers. comm. Oct. 2015) older than the LBA eruption have 


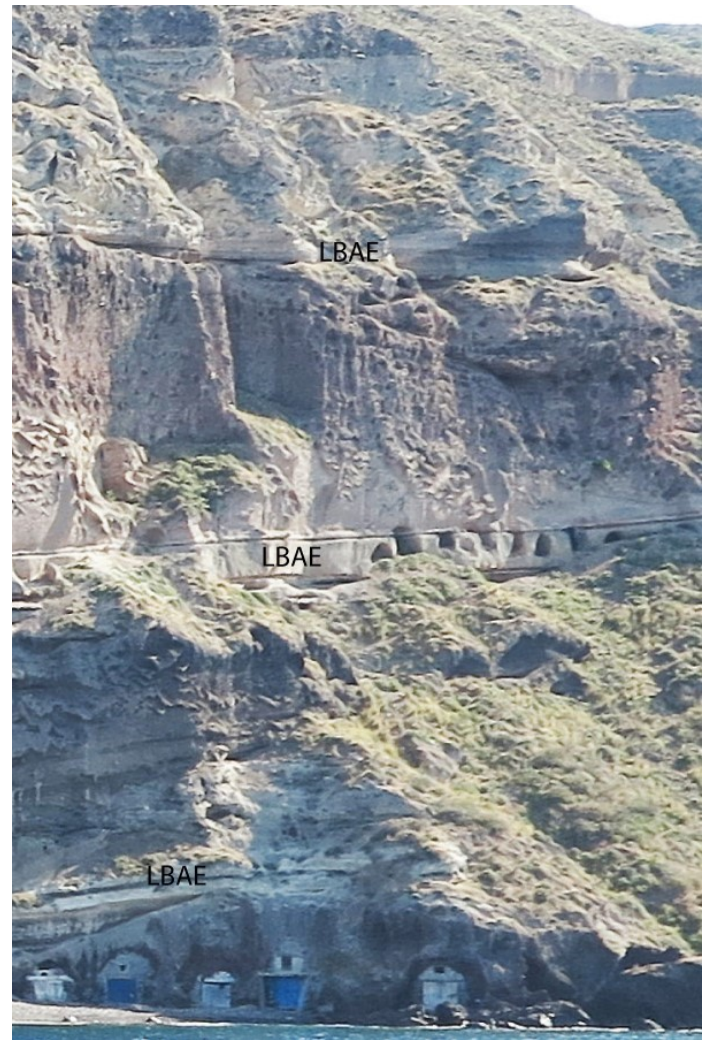

Figure 7. The pumice and ash of the LBA eruption had mantled the entire volcanic edifice including the inner side of the caldera. Erosion has removed most of it but remnants are still visible where concentric terraces existed on the wall. The caves of a former monastery above Balos harbour were dug into the pumice of the LBA eruption that is resting on a narrow concentric terrace.

been found in the Akrotiri excavation. We think that this pumice most probably came from Santorini itself, where several pumice layers are present in the caldera wall which was accessible in the Bronze Age.

The pumice used by the Thereans could be from, for example, the Cape Riva ignimbrite that outcrops in the Akrotiri excavation where houses are built partly on top of this ignimbrite and at "pillar 17" where it forms a clear edge. Furthermore, this welded ignimbrite is also exposed in the nearby Potamos Kamaras valley and the Mavromatis quarry (Figure $1(b) ; 12$ ) on Thera where rounded lumps of pumice up to $20 \mathrm{~cm}$ in diameter have been baked into the base of the welded ignimbrite. This site is quite close to an archaeological site where Cycladic houses of the Bronze Age were excavated [19]. In addition, the Phtellos excavation [34] near Fira shows no trace of an accessible major pumice layer.

\section{The Caldera Had a Mantle of Pumice from the LBA Eruption}

Only a few hundred meters from the Cycladic house which had been excavated by Gorceix and Mamet in 1874 we observed that 10 caves were dug into the soft pumice of the first eruption phase of the LBA eruption. When we studied the caldera wall in detail it became evident that the same LBA eruption products 
were repeated three times on the caldera wall above Balos harbour, indicating that the pumice and ash of the LBA eruption had mantled the entire volcanic edifice, including the inner side of the caldera. Erosion has removed most of it but remnants are still visible where concentric terraces existed on the wall. The caves of a former monastery above Balos harbour were dug into the pumice of the LBA eruption that is resting on a narrow concentric terrace. They all have a horizontal depth of about 4.5 meters where the cave diggers met the hard rock of the marine block of the Akrotiri Peninsula (Figure 7). The system of concentric terraces could be used as roads and shelter for the inhabitants of the pre-LBA eruption ring-island.

\section{Discussion}

One could argue that the LPS was locally eroded away prior to the LBA eruption, but it has not been found in drillings or at excavation sites. Furthermore, the so-called LPS deposits in deep-sea drillings are not from Santorini. Archaeological evidence of Cycladic objects at several localities under the so-called LPS proves that these objects were buried by the LBA eruption and not by an older layer of pumice some 200,000 years ago. Its products were partly deposited on the inner side of the commonly steeply sloping caldera wall. The topography, slumping and later erosion led to difficulties in interpreting the local stratigraphy.

\section{Conclusions}

A water-filled caldera existed at Santorini before the LBA eruption. The LBA pumice draped the entire landscape and was thickest on terraces on the caldera wall (Figure 2(d)). After erosion, pumice remained on terraces at distinct levels (Figure 7). Pumice on two major terraces was interpreted as being formed by separate explosive volcanic eruptions 200,000 years apart, but in fact were both part of the same LBA eruptive event. Study of the caldera wall and localities on Thera suggests that the LPS does not exist and the magmatic cycle theory is consequently invalid. The pumice below Fira was deposited on the inner side of an existing caldera during the LBA eruption. The caldera wall, consisting of lavas and pyroclastic layers, was intersected by radial and concentric faults. We deduce this from small eruption points arranged in curved tectonic lines which predate the LBA eruption. Tectonic events gave rise to curved terraces and niches on the caldera wall upon which the products of the LBA eruption were deposited. These deposits have been partly reworked by down-sliding since they contain xenoliths of older pyroclastic material, such as dark lapilli from the older Upper Scoria Series. This can possibly also explain the old radiometric data obtained for the LPS and its slightly darker colour. The locality below Oia where Druitt [21] sampled is an isolated occurrence of welded pumice which could be a relic of an old intra-caldera volcano.

One could argue that the LPS was locally eroded away prior to deposition of the LBA eruption, but it has not been found in drillings or at excavation sites. 
Furthermore, the so-called LPS deposits in deepsea drillings are not from Santorini. Archaeological evidence of Cycladic objects at several localities under the so-called LPS proves that these objects were buried by the LBA eruption and not by an older layer of pumice. Rediscovery of an old excavation site at Balos helped us to solve a 150 years old enigma: both the so-called LPS and the UPS were deposited by the same LBA eruption around $1613 \mathrm{BC}$. Its products were partly deposited on the inner side of the commonly steeply sloping caldera wall. The topography, slumping and later erosion led to difficulties in interpreting the local stratigraphy.

\section{Acknowledgements}

We thank Michael and Jeppe Lykke Friedrich for help with the fieldwork and Giorgios Nomikos for logistic assistance. Grethe Storgaard assisted with drawings.

\section{Author Contributions}

All the authors performed fieldwork and discussed the manuscript equally. A.H.S. contributed with archaeological research. M.F. provided drill data. W.L.F., A.H.S. and J.R.W. wrote the manuscript.

\section{References}

[1] Fouqué, F. (1879) Santorin et ses Éruptions. Masson \& Cie, Paris.

[2] Pichler, H. and Friedrich, W.L. (1980) Mechanism of the Minoan Eruption of Santorini. In: Doumas, C., Ed., Thera and the Aegean World II, The Thera Foundation, London, 15-30.

[3] Druitt, T.H., Mellors, R.A., Pyle, D.M. and Sparks, R.S.J. (1989) Explosive Volcanism on Santorini, Greece. Geological Magazine, 26, 95-126. https://doi.org/10.1017/S0016756800006270

[4] Heiken, G. and McCoy, F. (1990) Precursory Activity to the LBA Eruption, Thera, Greece. In: Hardy, D.A., Ed., Thera and the Aegean World III.2, The Thera Foundation, London, 79-88.

[5] Friedrich, W.L., Kromer, B., Friedrich, M., Heinemeier, J., Pfeiffer, T. and Talamo, S. (2006) Santorini Eruption Radiocarbon Dated to 1627-1600 B.C. Science, 312, 548. https://doi.org/10.1126/science.1125087

[6] Sørensen, A.H. and Friedrich, W.L. (2009) Time Table. In: Warburton, D.A., Ed., Time's Up! Dating the LBA Eruption of Santorini: Acts of the LBA Eruption Chronology Workshop, Sandbjerg November 2007. Aarhus Universitetsforlag, Aarhus.

[7] Pfeiffer, T. (2003) Two Catastrophic Volcanic Eruptions in the Mediterranean-Santorini 1645 B.C. and Vesuvius 79 A.D. PhD Dissertation, Department of Earth Sciences, Aarhus University.

[8] McCoy, F. (2009) The Eruption within the Debate about the Date. In: Warburton, D.A., Ed., Time's Up! Dating the LBA Eruption of Santorini: Acts of the LBA Eruption Chronology Workshop, Sandbjerg, November 2007, Aarhus University Press, Aarhus, 73-90.

[9] Soles, J. S. (2009) The Impact of the LBA Eruption of Santorini on Mochlos, a Small Minoan Town on the North Coast of Crete. In: Warburton, D.A., Ed., Time's Up! 
Dating the Minoan Eruption of Santorini: Acts of the Minoan Eruption Chronology Workshop, Sandbjerg November 2007. Aarhus University Press, Aarhus, 107-116.

[10] Stanley, D.J. and Sheng, H. (1986) Volcanic Shards from Santorini (Upper Minoan Ash) in the Nile Delta, Egypt. Nature, 320, 733-735. https://doi.org/10.1038/320733a0

[11] Bruins, H.J., MacGillivray, J.A., Synolakis, C.E., Benjamini, C., Keller, J., Kisch, H.J., Klügel and van der Plicht, J. (2008) Geoarchaeological Tsunami Deposits at Palaikastro (Crete) and the Late Minoan IA Eruption of Santorini. JAS, 35, 191-212.

[12] Bertemes, F. (2013) Tavsan Adasi. Das Thera-Event und seine Auswirkung auf das minoische Kommunikations-netzwerk. In: Meller, H., Bertemes, F., Bork, H.-R. and Risch, R., Eds., 1600-Cultural Change in the Shadow of the Thera-Eruption? Landesmuseum für Vorgeschichte, Halle (Saale), 191-210.

[13] Goodman-Tchernov, B.N., Dey, H.W., Reinhardt, E.G., McCoy, F. and Mart, Y. (2009) Tsunami Waves Generated by the Santorini Eruption Reached Eastern Mediterranean Shores. Geology, 37, 943-946. https://doi.org/10.1130/G25704A.1

[14] Keller, J., Gertisser R., Reusser, E. and Dietrich, V. (2014) Pumice Deposits of the Santorini Lower Pumice 2 Eruption on Anafi Island, Greece: Indications for a Plinian Event of Exceptional Magnitude. Journal of Volcanology and Geothermal Research, 278-279, 120-128. https://doi.org/10.1016/j.jvolgeores.2014.04.009

[15] Neumann van Padang, M. (1936) Die Geschichte des Vulkanismus Santorins von ihren Anfängen bis zum zerstörenden Bimssteinausbruch um die Mitte des 2. Jahrtausend vor Christus. In: Reck, H., Ed., Santorin-Der Werdegang eines Inselvulkans und sein Ausbruch 1925-1928, Vol. I., D. Reimer Verlag, Berlin, 1-72.

[16] Ninkovich, D. and Heezen, B.C. (1967) Physical and Chemical Properties of Volcanic Glass Shards from Pozzuolana Ash, Thera Island, and from Upper and Lower Ash Layers in Eastern Mediterranean Deep Sea Sediments. Nature, 213, 582-584. https://doi.org/10.1038/213582a0

[17] Vinci, A. (1985) Distribution and Chemical Composition of Tephra Layers from Eastern Mediterranean Abyssal Sediments. Marine Geology, 64, 143-155. https://doi.org/10.1016/0025-3227(85)90165-3

[18] Pichler, H. and Kussmaul, S. (1980) Geological Map. In: Doumas, C.G., Ed., Thera and the Aegean World II, The Thera Foundation, London, Appendix.

[19] Hammer, C.U., Clausen, H.B., Friedrich, W.L. and Tauber, H. (1987) The Minoan Eruption of Santorini in Greece Dated to 1645 BC? Nature, 328, 517-519. https://doi.org/10.1038/328517a0

[20] Sparks, R.S.J. and Wilson, C.J.N. (1990) The Minoan Deposits: A Review of Their Characteristics and Interpretation. In: Hardy, D.A., Ed., Thera and the Aegean World III.2, The Thera Foundation, London, 89-99.

[21] Vitaliano, C.J., Taylor, S.R., Norman, M.D., McCulloch, M.T. and Nicholls, I.A. (1990) Ash Layers of the Thera Volcanic Series: Stratigraphy, Petrology and Geochemistry. In: Hardy, D.A., et al., Eds., Thera and the Aegean World III.2, The Thera Foundation, London, 53-78.

[22] Druitt, T.H., Edwards, L., Mellors, R.M., Pyle, D.M., Sparks, R.S.J., Lanphere, M., Davies, M. and Barriero, B. (1999) Santorini Volcano. Geological Society Memoir No. 19. Geological Society of London, London.

[23] Heiken, G. and McCoy, F. (1984) Caldera Development during the Minoan Eruption, Thira, Cyclades, Greece. Journal of Geophysical Research, 89, 8441-8462. https://doi.org/10.1029/JB089iB10p08441

[24] Seward, D., Wagner, G.A. and Pichler, H. (1980) Fission Track Ages of Santorini 
Volcanics (Greece). In: Doumas, C.G., Ed., Thera and the Aegean World II, The Thera Foundation, London, 101-108.

[25] Nomikou, P., Papanikolaou, D., Tibaldi, A., Carey, S., Livanos, I., Bell, K.L.C., Pasquarè, F.A. and Rousakis, G. (2013) The Detection of Volcanic Debris Avalanches along the Hellenic Volcanic Arc, through Marine Geophysical Techniques. In: Lamarche, G., et al., Eds., Submarine Mass Movements and Their Consequences, Springer, Berlin, 337-349.

[26] Eriksen, U., Friedrich, W.L., Buchardt, B., Tauber, H. and Thomsen, M.S. (1990) The Stronghyle Caldera: Geological, Palaeontological and Stable Isotope Evidence from Radiocarbon Dated Stromatolites from Santorini. In: Hardy, D.A., Ed., Thera and the Aegean World III.2, The Thera Foundation, London, 139-150.

[27] Druitt, T.H. and Francaviglia, V. (1990) An Ancient Caldera Cliff Line at Phira, and Its Significance for the Topography and Geology of Pre-Minoan Santorini. In: Hardy, D.A., Ed., Thera and the Aegean World III.2, The Thera Foundation, London, 362-369.

[28] Mamet, H. (1874) De insula Thera. Lille.

[29] Seidenkrantz, M.S. (1989) Foraminiferfauna fra Akrotirihalvøen. Georapporter, 11, 22-25.

[30] Friedrich, W.L. (2009) Santorini: Geology, Natural History, Mythology. Aarhus University Press, Aarhus.

[31] Friedrich, W.L., Friborg, R. and Tauber, H. (1980) Two Radiocarbon Dates of the Minoan Eruption on Santorini (Greece). In: Doumas, C.G., Ed., Thera and the Aegean World II, The Thera Foundation, London, 241-243.

[32] Friedrich, W.L. (2000) Fire in the Sea. Cambridge University Press, Cambridge.

[33] Fytikas, M., Karydakis, Gr., Kavouridis, Th., Kolios, N. and Vougioukalakis, G. (1990) Geothermal Research on Santorini. In: Hardy, D.A., Ed., Thera and the Aegean World III.2, The Thera Foundation, London, 241-249.

[34] Marthari, M. (1980, 1988) Thera, “Phtellos”. Arch. Delt. 35; Chronica, 472-473.

\section{Submit or recommend next manuscript to SCIRP and we will provide best service for you:}

Accepting pre-submission inquiries through Email, Facebook, LinkedIn, Twitter, etc. A wide selection of journals (inclusive of 9 subjects, more than 200 journals)

Providing 24-hour high-quality service

User-friendly online submission system

Fair and swift peer-review system

Efficient typesetting and proofreading procedure

Display of the result of downloads and visits, as well as the number of cited articles

Maximum dissemination of your research work

Submit your manuscript at: http://papersubmission.scirp.org/

Or contact ijg@scirp.org 